\title{
Öğretmenlerin Uzaktan Hizmet İçi Eğitim Deneyimlerinin İncelenmesi
}

\section{Elif TAŞLIBEYAZ, Selçuk KARAMAN, Yüksel GÖKTAŞ*}

\begin{abstract}
Öz
Uzaktan eğitimin temelinde; teknolojiyi kullanarak öğrenenlere kolay erişilebilir ve esnek bir eğitim imkânı sağlamak yatmaktadır. Bu esneklik uzaktan eğitimin hizmet içi eğitimlerde kullanımı yaygınlaştırmaktadır. Bu çalışmada öğretmenlerin, katıldıkları uzaktan hizmet içi eğitim hakkındaki görüşlerinin ve motivasyonlarını etkileyen etmenlerin tespit edilmesi amaçlanmıştır. Bunun için bu araştırmada, öğretmenlerin uzaktan hizmet içi eğitim uygulamalarına ilişkin görüşlerine odaklanılmıştır. Araştırmanın katılımc1 grubunu; 2011-2012 eğitim-öğretim yılında Erzurum ilindeki bir ilköğretim okulunda görev yapan ve uzaktan hizmet içi programına katılan 21 öğretmen oluşturmaktadır. Öğretmenlerin katıldığı bu uzaktan hizmet içi eğitim programı, "Aşamalı Devamsızlık Yönetimi Eğitimi" ve "Afet Eğitimi" konularını kapsamaktadır. Bir durum çalışması olarak yürütülen bu araştırmada veriler, nitel yöntemlerle toplanıp analiz edilmiştir. Sonuçta; öğretmenlerin uzaktan hizmet içi eğitim uygulamalarını tercih edilebilir buldukları ortaya çıkmıştır. Bu noktada, uzaktan eğitimlerin zaman ve mekân serbestliği sağlamasının yanı sıra bu eğitimlerin daha ilgi çekici ve erişilebilir olmasının etkili olduğu görülmüştür. Bununla birlikte öğretmenlerin, bazı teknik aksaklıkların yaşanması ve programda etkileşim sınırlılığının olması ile ilgili olarak olumsuz görüş bildirdikleri ortaya çıkmıştır.
\end{abstract}

Anahtar kelimeler: Uzaktan eğitim, hizmet içi eğitim,öğretmen görüşleri.

\footnotetext{
* Doç. Dr., Atatürk Üniversitesi Kazım Karabekir Eğitim Fakültesi, yukselgoktas@atauni.edu.tr
} 


\title{
Examining The Experiences of Teachers Received In Service Training Through Distance Education
}

\begin{abstract}
Providing easily accessiable and flexible education opportunities by using technology underlies the distance education. Thanks to the flexibility, the use of distance education in in-service trainings becomes popular. The purpose of this study is to determine teachers' views and the factors of that affect motivation about distance in-service training. So in this study, we focus on teachers' views about distance education practices. Participant group of the study contains 21 teachers who work in 2011-2012 educational year and participates distance inservice education programme in Erzurum. This training programme contains "Gradual Absence Training" and "Disaster Training". In this study that is applied as case study, the datas are collected and analysed by using qualitative method. In conclusion, distance in-service training applications are found preferable by teachers. At this point, besides this education provides place and time flexibility, it also seen to be effective because of being more interesting and accessible. However, it is seen that teachers expressed a negative opinion about existence of technical problems and limitation of interaction.
\end{abstract}

Keywords: Distance education, in-service training, teachers views 


\section{Giriş}

Uzaktan eğitim; eğitimcilere geniş kitlelere ulaşan çok büyük bir çalışma alanı sunmuştur. Bu çalışma alanı, teknolojiyi kullanarak öğrencilere kolay, ucuz ve esnek bir eğitim imkânı sağlamak için kullanılmaktadır (Horton, 2000). Bu sebeple uzaktan eğitim başta eğitim kurumları olmak üzere çok sayıda kurumun dikkatini çekmiş (Driscoll, 2002) ve dünya genelinde yaygınlaşmaya başlamıştır (Kesim, 2004).

Uzaktan eğitimin yaygınlaşması, bugünkü haliyle uzaktan eğitim sistemlerinin; yeni kavramlar, işlevler ve yöntemler oluşturma, eğitimi demokratikleştirme, uygulamalarda esneklik sağlama, süreçlere çok boyutluluk kazandırma gibi noktalarda eğitime katkılar sağlaması ile ilişkilendirilebilir (Elmas, Bay, Yiğit, Yılmaz ve Karataş, 2007). Ayrıca uzaktan eğitimin öğrencileri, medya araçları yardımıyla öğrenmeye motive ettiği (Stafford, 2005), çok daha esnek ve ulaşılabilir olması ile olumlu yönde etkilediği (Hammond, Rennie ve Dickson, 2007; Tao, 2008) bilinmektedir. Bununla birlikte, uzaktan eğitimin yüz yüze eğitimden daha etkili olup olmadığı tartışılmaktadır (Horzum ve Balta, 2008). Ancak böyle bir kıyaslamada öğrenme hedefleri ve öğrenen koşullarının göz önünde bulundurulması ve uygulanabilirliğin incelenmesi gerekir. Yine de bazı çalışmalarda öğrencilerin, uzaktan verilen eğitimi örgün eğitime göre daha etkili bulduğu ve bu eğitimin teknoloji kullanımını geliştirdiği tespit edilmiştir (Laraia, Dodds, Benjamin, Jones ve Carbone, 2008; Hoesing, 2004).

\section{Öğretmen Eğitiminde Uzaktan Eğitim}

Günümüzde yaşam boyu öğrenme, ulusal ve uluslararası politikanın bir parçası olarak yeni çalışmalara uyum sağlamak için zorunlu hale gelmiştir (Sonyel, 2004). Yaşam boyu öğrenme kavramının önemli hale gelmesi ve eğitim teknolojileri alanında yaşanmakta olan gelişmeler sebebiyle bir insanın sahip olması gereken mevcut bilgi birikimi de sürekli artmaktadır. Öğretmenlerin de bu artan bilgi birikimini ve gelişmeleri takip ederek kendini yenilemesi mecburiyet halini almıştır (Özkan, 2005). Bu nedenle öğretmenlerin sürekli eğitim ihtiyacı göz önünde bulundurulmalıdır.

Dünyada ve Türkiye'de çeşitli uzaktan hizmet içi öğretmen eğitimleri yapılmaktadır (Gültekin, 2006). Uzaktan öğretmen eğitimi, temel yeteneklerin kazandırılması, bazı becerilerin geliştirilmesi ve kariyer gelişimlerinin desteklenmesi amaçlarıyla kullanılmaktadır (Perreaton, Creed ve Robinson, 2001). Bu uygulamalarda minimum enerji ile gerekli öğretimsel içeriğe ulaşabilme (Stafford, 2005) ve zaman, yer sıkıntısı olan kişiler için alternatif 
seçenekler oluşturma (Hoesing, 2004; Hammond, vd., 2007) zorunluluğu önemli rol oynamaktadır.

Uzaktan öğretmen eğitimine yönelik uygulamalara ilişkin sonuçlar incelendiğinde, öğretmenlerin uzaktan eğitimi etkili ve memnuniyet verici bulduğu, teknoloji algısını ve teknolojiye karşı güvenlerini iyileştirdiği görülmektedir (Yuena ve Mab, 2008; Cavas, Cavas, Karaoğlan ve Kışla, 2009; Hall ve Knox, 2009). Ayrıca öğretmenler uzaktan hizmet içi eğitim sayesinde meslektaşları ile haberleşip, mesleki kazanç sağlamakta, güncel bilgi ve uygulamalar hakkında etkin şekilde bilgi sahibi olmaktadırlar (Gillies, 2008). $\mathrm{Bu}$ kazanımlar ve elde edilen bilgi ve becerilerin sınıf içi eğitimlere yansımaları göz önüne alındığında tüm öğretmenlerin uzaktan hizmet içi eğitimle tanıştırılması gerektiği düşünülebilir (Gültekin, 2006). Ancak eğitimlerin etkili ve verimli olması açısından uygulamaların sürekli değerlendirilmesine ve yeni eğitimlerin bu doğrultuda tasarlanmasına ihtiyaç olduğu da söylenebilir.

\section{Teorik Çerçeve}

Öğretmenlerin uzaktan hizmet içi eğitimlerine ilişkin görüşlerine odaklanan bu çalışmanın teorik çerçevesini Moore'un "Etkileşimsel Uzaklık Teorisi" oluşturmaktadır. Etkileşimsel Uzaklık Teorisinde Moore (1993), uzaktan öğrenme ortamlarında bireylerarası iletişimin önemini vurgulamış ve uzaktan eğitimde öğrenen ve öğretici arasındaki uzaklığın kaynağını tanımlamaya çalışmıştır. Moore, uzaklıktan bahsederken öğrenen ve öğreticinin fiziksel olarak ayrı mekânlarda olmasını değil, öğrenen tarafından hissedilen psikolojik uzaklığı ifade eder. Psikolojik uzaklık ise gerek öğrenen-öğrenen, gerekse öğrenen-öğretici arasındaki iletişimin eksikliğinden kaynaklandığı düşünülebilir. Bu nedenle eğitim ihtiyacının karşılanması için uzaktan eğitim uygulamalarına da yer verilebilir (Moore, 1993). Etkileşimsel Uzaklık Teorisi'ne göre bir uzaktan eğitim programında bulunması gereken aşamalar ise şöyledir; sunum, motivasyon, analiz, öneriler ve değerlendirme.

\section{Araştırmanın Gerekçesi ve Önemi}

Öğretmenlere yönelik yeni uygulama ve yönetmelikler, ortaya çıkan yeni öğretim teknolojileri ve diğer mesleki gelişim ihtiyaçları, öğretmenler için hizmet içi eğitimleri zorunlu kılmaktadır. Bu nedenle öğretmenlere periyodik olarak eğitim desteği verilmektedir. Öğretmen sayısının fazla olması, öğretmenlerin mesleki ve kişisel sorumluluklarını aksatmaksızın eğitim alabilmeleri açısından uzaktan eğitim iyi bir alternatif olabilir. 
Etkili ve kabul edilebilirliği yüksek uzaktan eğitim programlarının tasarlanması için bu tür eğitim uygulamalarının değerlendirilmesi ve öğretmenlerin bu eğitimlere yönelik görüşlerinin belirlenmesi gereklidir. Ancak konu ile ilgili literatür incelendiğinde öğretmenlere verilen hizmet içi eğitimin uzaktan eğitim yoluyla uygulanmasına ilişkin araştırmaların yeterli olmadığı görülmektedir.

Öğretmenlerin, hizmet içi uzaktan eğitim uygulamalarıyla ilgili deneyimlerine odaklanan bu çalışma öğretmen eğitimi ile ilgili hem literatüre hem de yeni uygulamalara katkı sağlayabilecektir. Bu araştırma öncelikle öğretmenlerin uzaktan eğitime yatkınlıklarına ilişkin fikir vermesi açısından önemlidir. Bununla birlikte bu çalışma, uzaktan hizmet içi eğitimdeki potansiyel ve sınırlılıkların öğretmen perspektifinden ortaya konulması, eğitimlerin planlanması ve kaynakların etkili kullanılmasına ilişkin ipuçları verecektir.

\section{Araştırmanın Amacı}

Yapılan araştırmada, öğretmenlerin, katıldığı uzaktan hizmet içi eğitim deneyimlerinin incelenmesi amaçlanmıştır. Araştırmanın amacı, çerçevesinde odaklanılan araştırma soruları ise şu şekildedir;

1. Öğretmenlerin katıldıkları uzaktan hizmet içi eğitim uygulaması hakkındaki görüşleri nelerdir?

- Öğretmenler uzaktan hizmet içi eğitimi tercih edilebilir buluyor mu?

- Uzaktan hizmet içi eğitimin güçlü yönleri nelerdir?

- Uzaktan hizmet içi eğitimin sınırlılıkları nelerdir?

- Uzaktan hizmet içi eğitimin etkili olma durumu ve daha etkili olması için sunulan öneriler nelerdir?

2. Uzaktan hizmet içi eğitimde motivasyonu etkileyen etmenler nelerdir?

\section{Yöntem}

\section{Araştırma Deseni}

Bu çalışma, nitel araştırma yönteminin kullanıldığı bir durum çalışmasıdır. Durum çalışması; doğal bir çevre içinde gerçekleştirilen ve çalışmaya konu olan ortam veya olayların bütüncül yorumunu hedefleyen bir araştırma yöntemidir (Yıldırım \& Şimşek, 2008). Bu araştırmada durum çalışmasının kullanılma sebebi olarak; uzaktan hizmet içi eğitim almış olan öğretmenlerin, uzaktan 
eğitim hakkındaki görüşlerinin doğal ortamda incelenmesine imkân veren, insanların görüş, yargı ve algılarını ortaya koyan, böylece konuyu derinlemesine incelemeyi sağlayan bir yöntem oluşu gösterilebilir.

\section{Katılımcilar}

Araştırmanın katılımcı grubunu; 2011-2012 eğitim-öğretim yılında Erzurum ilindeki bir ilköğretim okulunda görev yapan 21 öğretmen oluşturmaktadır. Bu öğretmenler, yaşları 25-50 arasında değişen ve uzaktan hizmet içi eğitime katılmış olan 30 öğretmen arasından kolay ulaşılabilir durum örneklemesine göre seçilmiştir. $\mathrm{Bu}$ örnekleme yöntemi, araştırmaya hiz ve pratiklik kazandıracağı için tercih edilmiştir.

\section{Uygulama Süreci}

Öğretmenlere yönelik olarak hazırlanan uzaktan hizmet içi eğitim programında, "Aşamalı Devamsızlık Yönetimi Eğitimi" (ADEY) ve "Afet Eğitimi" konuları bulunmaktadır. Programın içeriğinde ADEY Eğitimi ile Afet Eğitiminde yapılması gerekenlerin görsel, video ve animasyonlarla anlatımı yer almaktadır. Konuların çalışııp cevaplanması gereken süre bir aydır. Konu aralarında çoktan seçmeli, boşluk doldurma tipinde, konu sonunda ise çoktan seçmeli sorular bulunmaktadır. Öğretmenlerin, hizmet içi eğitimi tamamlamaları için içerik sunumlarını okuyarak, izleyerek veya dinleyerek takip etmeleri, konu arasında verilen soruları cevaplamaları ve konu sonundaki testi cevaplandırmaları gerekmektedir.

\section{Veri Toplama Aracı}

Bu çalışmada, öğretmenlerin uzaktan eğitim ile ilgili deneyimlerini ortaya çıkarmak için görüşmeler yapılmasına karar verilmiştir. $\mathrm{Bu}$ doğrultuda hazırlanan görüşme sorularında; Moore'un (1993) "Etkileşimsel Uzaklık" teorisinin; öğretmenlerin görüşlerini belirlemek için "sunum", öğretmenlerin memnuniyet durumlarını fark etmek içinse "motivasyon" aşamalarından faydalanılmıştır. Hazırlanan taslak görüşme formu araştırmanın amacına ve teorik çerçeveye uygunluğu açısından uzman değerlendirmesine tabi tutulmuş ve değerlendirmeler sonucunda iyileştirmeler yapılmıştır. Ayrıca görüşme formu sorularının anlaşılabilirliğini artırmak için Türkçe dil uzmanına kontrol ettirilerek son haline getirilmiştir. Form yardımıyla iki öğretmenle pilot görüşme yapıldıktan sonra yeniden revize edilmiş ve görüşme sorularına yeni sondalar eklenmiştir. 
Alan ve dil uzmanlarının görüşleri ve pilot uygulama verileri doğrultusunda yapılan revizyonlar sonunda 9 sorudan oluşan yarı-yapılandırılmış, bir görüşme formu hazırlanmıştır (Yıldırım ve Şimşek 2008). Hazırlanan görüşme sorularından 3., 4., 5., 6., 7., 8., 9. soruların sunum, 1., 2. soruların ise motivasyon basamağındaki yeterliklere yönelik olması sağlanmıştır. Ayrıca görüşme sorularını zenginleştirmek için görüşme sırasında ek sorular ve sondalardan faydalanılmıştır.

Hazırlanan bu görüşme formu, seçilmiş olan katılımcılara araştırmacılar tarafından uygulanmış ve konuşmalar, -kişilerden izin alınarak- ses kayıt cihazı ile kayıt altına alınmıştır. Görüşmelerin her biri ortalama 15 dakika sürmüştür.

\section{Veri Analizi}

Uygulamanın bitiminde öğretmenlerin görüş ve düşüncelerine ilişkin veriler, nitel yöntemlerle toplanıp analiz edilmiş ve bu verilerin çözümlenmesinde içerik analizi yöntemi kullanılmıştır. Bunun için birinci ve ikinci araştırmacı tarafından ayrı ayrı dört adet görüşme kaydı analiz edilmiş, kod ve temalar oluşturulmuştur. Daha sonra bu tema ve kodlar üzerinde araştırmacılar arasında birliktelik sağlanacak şekilde gerekli düzeltmeler yapılmıştır. Sonrasında tüm transkriptler araştırmacılar tarafından analiz edilmiştir.

Analiz sonucu ortaya çıkan kod ve temalar yardımıyla elde edilen nitel veriler, araştırmanın amaçları doğrultusunda sayısallaştırılarak frekans tabloları halinde sunulmuştur. Bulgular ise katılımcıların görüşlerinden doğrudan alıntılar eşliğinde sunulmuştur.

\section{Geçerlik-Güvenirlik}

Araştırmanın, geçerlik ve güvenirliğinin sağlanması amacıyla araştırma süreci net bir şekilde açılanmıştır. Görüşme formu, araştırma sorularına göre "Etkileşimsel Uzaklık" teorisinin sunum ve motivasyon basamaklarından yararlanılarak oluşturulmuştur. Görüşme formu tasarımında uzman öğretim elemanlarının görüşleri göz önünde bulundurulmuştur.

Analiz aşamasında ise araştırmacılar öncelikle bağımsız olarak birkaç görüşme kaydını analiz etmiş, ortak kod ve temalar oluşturmuşlardır. Sonrasında tüm veriler analiz edilmiş, gerekli durumlarda kod ve temalarda güncellemeler yapılmıştır. 


\section{Bulgular}

Elde edilen bulgular, araştırma soruları temel alınarak ana ve alt başlıklar altında toplanmıştır. Görüşme sonuçlarından elde edilen tematik alanlar, frekans tablolarında sunulmuştur. Ayrıca oluşturulan tematik alanlara ilişkin doğrudan alıntılara yer verilmiştir. Hangi alıntının hangi katılımcı tarafından ifade edildiğini belirtmek için ise katılımcı isimleri gizli tutulmuş ancak görüşme sırasına göre Ö1, Ö2 şeklinde kodları kullanılmıştır.

\section{Uzktan Hizmet içi Eğitimde Motivasyonu Etkileyen Etmenler}

Öğretmenlerin uzaktan hizmet içi eğitim uygulamalarında kendilerini motive eden unsurlarla ilgili görüşleri analiz edilmiştir. Bu analiz sonuçlarına göre öğretmenlerin çoklu ortam materyallerinin kullanımı, öğrenen-içerik etkileşimleri ve uzaktan eğitimin sunduğu esneklik üzerinde durdukları görülmektedir. Analizde ortaya çıan ilgili kodlar ve frekans değerleri Tablo 1 'de gösterilmiştir.

Tablo 1. Uzaktan hizmet içi eğitimde motivasyonu etkileyen etmenler

\begin{tabular}{lc}
\hline Tema/Kodlar & S1klık $(f)$ \\
\hline Görseller & 11 \\
& \\
Video anlatımları & 10 \\
Soru/cevaplar & 5 \\
Zaman/ortam kisıtlamasının & 5 \\
olmaması & \\
Ses tonu uygun/sesli anlatım & 2 \\
Güncel bilgiler bulunması & 2 \\
Tekrar olanağı & 1 \\
\hline
\end{tabular}

Tablo 1'de görüldüğü gibi uzaktan hizmet içi eğitimde uygulamasındaki sunum ve materyal çeşitliliği, motivasyonu etkileyen bir unsur olarak ele alınmıştır. Bu kapsamda görsel, video, animasyon ve sesli anlatımların bulunmasına dikkat çekilmiştir. Sunumların çoklu ortam materyalleriyle desteklenmesine yönelik görüşler, materyallerin ilgi ve dikkati sağlamasında çeşitliliğin yanı sıra teknik, pedagojik ve görsel açıdan nitelikli olmalarının etkili olduğunu göstermektedir. Öğretmen görüşlerinde ayrıca, çoklu ortam unsurları içermemesine rağmen soru-cevap şeklindeki etkileşimli alıştırmaların ilgiyi artırdığı ortaya çıkmıştır. Materyaller konusundaki yorumlardan bazıları aşağıdaki gibidir; 
Öğretmenlerin Uzaktan Hizmet İçi Eğitim Deneyimlerinin İncelenmesi

"Öncelikle görsel materyaller kullanildığı için motivasyonu kahıc hale getirmiş. Konuyla ilgili görsel materyallerin, videoların, canlandırmaların kullanılması konuyu ilgi çekici hale getirmiş diyebilirim."(Ö1)

“Bu eğitimi çok farklı buldum. Yüz yüze eğitimde anlatıcılarn birçoğu ses tonunu ayarlayamıyor, ifade yeteneği zayıf olanlar var. Uzaktan eğitimde böyle bir sorun yok." (Ö18)

Öğretmen görüşlerinde öne çıkan diğer bir husus ise uzaktan eğitimin esnekliğidir. Öğretmenler, öğrenme etkinliklerine zaman-ortam kısıtlaması olmaksızın katılabilmelerinin motivasyonu artırdığını düşünmektedirler. Bu konu ile ilgili yorumlardan biri aşağıdaki gibidir;

"Bu semineri oldukça uygun buldum. Yüz yüze ĕgitime göre zaman kısıtlaması olmaması, kişinin müsait olduğu zamanlarda yapılabilmesi uygulayıcı açısından iyiydi." (Ö16)

\section{Öğretmenlerin Uzaktan Hizmet içi Eğitim Semineri Hakkındaki Görüşleri olmasi. \\ Uzaktan eğitim yoluyla yapılan hizmet içi eğitimin tercih edilebilir}

Öğretmenlere uzaktan hizmet içi eğitimi ileride tercih edip, etmeyecekleri sorulmuş ve cevaplar analiz edilmiştir. Öğretmenlerin çoğunun, bir dahaki sefere yapılacak olan hizmet içi eğitimde uzaktan eğitimi tercih ettikleri görülmüştür. Uzaktan hizmet içi eğitimi tercih eden öğretmenlerin sayısı 18, etmeyenlerin sayısı ise üç'tür. Bu öğretmenler, uzaktan eğitimi tercih sebepleri olarak; kolay bir eğitim süreci olması, zamanın etkili kullanılabilmesi, bu eğitimin yüz yüze olana göre daha kalıcı olması, daha iyi öğrenme sağlaması, kullanılan sunum materyalleri ile zevkli bir öğretim süreci oluşturmasını göstermişlerdir. $\mathrm{Bu}$ eğitimi tercih etmeyen öğretmenler ise, programdaki etkileşim azlığından yakınmışlardır. Uzaktan hizmet içi eğitimin tercih edilmesine yönelik öğretmen görüşlerinden bazıları aşağıdaki gibidir;

"Evet, uzaktan eğitimi tercih ederim, çünkü daha kolay ve rahat bir eğitim süreci olduğunu düşünüyorum." (Ö14)

"Evet, bu eğitimi daha çok, belirli bir saat veya belirli bir gün sımırlaması olmadı̆̆ için tercih ederim. Yani eğitimi alırken üzerinizde herhangi bir zaman baskısı yok"(Ö18) 
"Evet, tercih ederim. Çünkü zamanı etkili kullanabiliyorum ve bu sayede daha fazla ögrenebiliyorum" (Ö4)

Bu bulgular 1şığında, uzaktan eğitimlerin öğretmenlere zaman ve mekân serbestliği sağlamasının olumlu etki oluşturduğu görülmüştür. Bununla birlikte öğretmenlerin, bazı teknik aksaklıkların yaşanması ve etkileşim sınırlılığının olması ile ilgili olarak olumsuz görüş bildirdikleri ortaya çıkmıştır. Üstünlük ve sinırlılıklarla ilgili bulgular sonraki başlıklarda detaylı bir şekilde verilmiştir.

\section{Uzaktan hizmet içi eğitimin güçlü yönleri.}

Öğretmenlerin hizmet içi eğitimin uzaktan eğitim yoluyla verilmesinin yüz yüze eğitime göre avantajlarına ilişkin görüşleri analiz edilmiş, ifadelerin esneklik, sunum/materyal ve etkileşim temaları altında toplandığı görülmüş̧ür. Bu konuya ilişkin tema, kod ve frekanslar Tablo 2' de gösterilmiştir.

Tablo 2. Uzaktan hizmet içi eğitimin güçlü yönleri

\begin{tabular}{lc}
\cline { 1 - 2 } Tema/Kodlar & \multicolumn{2}{c}{ Sıklık $(f)$} & 16 \\
\cline { 1 - 2 } Esneklik & 6 \\
Zaman mekân zorunluluğu olmaması & 3 \\
Kalıcı olması & 3 \\
Bireysel öğrenmeyi sağlaması & \\
Tekrar olanağı sağlaması & 4 \\
Sunum & 4 \\
Motivasyonu sağlaması & 4 \\
Konuların basitten karmaşığa sıralanması & 3 \\
İsslevsel/açık ve net olması & 3 \\
İçeriklerin öz ve anlaşılır olması & 3 \\
İlgi çekici olması & \\
Görsellerin/videoların bulunması & 2 \\
Etkileşim & \\
Soruların Bulunması & \\
\end{tabular}

Tablo 2'de görüldüğü gibi, uzaktan hizmet içi eğitimin güçlü yönleri konusunda öğretmenler, uzaktan eğitimin doğası itibariyle sunduğu esneklik ve bireysel öğrenmeye uygunluğu üzerinde durmuşlardır. Bu noktada zaman 
ve mekân sorunu olmaksızın eğitime katılabilmenin rahatlığına vurgu yapılmıştır. Bu durum, öğretmenlerin hem işlerini aksatmamasını hem de konulara daha iyi odaklanmasını kolaylaştırması ile ilişkilendirilmektedir. $\mathrm{Bu}$ konu ile ilgili yorumlardan bazıları aşağıdaki gibidir;

"Bulunduğumuz ortamda ve istediğimiz anda uygulayabilmemizin bu seminerin üstün yönü olduğınu düşünüyorum"(Ö5)

"Semineri istediğimiz zamanda yapmamız, süre sinırlaması olmamasl, konuların sadece anlatımdan ibaret olmaması, monotonluğu en aza indirmişti bence" (Ö17)

"...anlaşllamayan konuları geriye alıp tekrar tekrar dinleyebilme imkânına sahip olmamız bir avantajdır diyebilirim" (Ö14)

Tablo 2'de görüldüğü gibi uzaktan hizmet içi eğitimlerin diğer bir üstünlüğü ise sunum/materyal niteliği ile ilgilidir. Bu tema, içeriklerin öz, anlaşılır biçimde çoklu ortam materyalleriyle desteklenerek sunulmasının bir üstünlük olarak görüldüğünü ortaya koymaktadır.

Detaylı olarak bakıldığında içerik boyutundaki üstünlüklerin, kısa ve öz anlatım, işlevsellik, ilgi çekicilikle ilişkilendirildiği görülür. Görüşlerde ayrıca içeriğin sunum formatı veya materyal vurgusu da yapılmıştır. İçeriklerin pek çok medya aracılığıyla desteklenerek sunulmasının bu eğitimi daha kalıcı ve ilgi çekici hale getirdiğine değinilmiştir. Bu konu ile ilgili yorumlardan bazıları aşağıdaki gibidir;

"Konu bitiminde soruların olması, filmlerle zenginleştirilmesi bu eğitimin üstün yönlerini oluşturuyor." (Ö11)

"Gereksiz bilgilerden kaçınılmış, gayet açık ve net. Yeteri kadar ve akılda kalacak nitelikte olduğunu düşünüyorum" (Ö3)

"Yüz yüze eğitimde daha çok düz anlatım mevcut, ya da herhangi bir siteden alelacele indirilmiş slaytlar mevcut. Uzaktan eğitimde ise güncel bilgiler, çarpıcı görseller ve gerekli yerlerde sesli anlatım ve videolarla zenginleştirilmiş halde bulunuyor." (Ö16)

Asenkron hizmet içi eğitim uygulamasının avantajlarına ilişkin ortaya çıkan diğer bir tema ise etkileşimdir. Sadece öğrenen-içerik etkileşimlerinin yer aldığı uygulamada, öğretmenlerin soru-cevap etkileşimlerini, geleneksel hizmet içi 
eğitim uygulamalarına göre bir üstünlük olarak gösterdiği ortaya çıkmıştır. Ayrıca etkileşimlerin konuları pekiştirme ve çalışmaya motive olma noktasında etkili olduğu ifade edilmiştir.

Uzaktan eğitimin güçlü yönlerinden biri de hizmet içi eğitim almayı kolaylaştırmasıdır. Uzaktan eğitimin hizmet içi eğitimi kolaylaştırdığını düşünen 20, kolaylaştırmakla birlikte eğitimi uygularken kişiyi yalnız bıraktığı için ciddiyeti azalttığını düşünen bir öğretmen bulunmaktadır. Bu konuya yönelik öğretmen görüşlerinden bazıları aşağıdaki gibidir;

"Uzaktan eğitimle daha fazla kişiye daha kolay ulaşmamız sağlanmaktadır. Ayrıca bu eğitimin belirli bir zaman diliminde yapılmaması, katılımonın istediği zamanda eğitimi alması, kolaylık sağlıyor tabii ki" (Ö17)

"Uzaktan eğitim istenilen zamanda uygulandığı için daha istekle ve daha çok kişiye ulaşma kolaylığı sağlıyor diye düşünüyorum." (Ö1)

Görüşme sonucunda ayrıca öğretmenlerin uzaktan eğitimi konuların anlaşılması açısından faydalı buldukları ortaya çıkmıştır. Bu görüşme sorusuna cevap veren 19 öğretmen, uzaktan eğitim uygulamasının konuların daha iyi anlaşılmasına vesile olduğunu açıklamıştır. İki öğretmen ise bu uygulamanın konuları daha iyi anlamayı sağlamadığı yorumunda bulunmuştur.

Konuları daha iyi anladığını söyleyen öğretmenler, konu aralarında ve sonunda soruların bulunması, konuların görsellerle desteklenmesi, eğitimin istenen zamanda yapılabilmesi hususuna değinmişlerdir. Bu konular ile ilgili öğretmen yorumlarından bazıları aşağıdaki gibidir;

"Evet, bilgi verilip ardindan görsellerle desteklenmesi ve bölüm sonlarında sorularla ögrrendiklerimizi denetlemesi iyi anlamama vesile oldu." (Ö17)

"Konuyu aldiktan sonra konu sonundaki değerlendirme sorularının olması konuyu geliştirmeye destek oluyor. Soruları cevaplamak da insanı daha çok şey öğrenmeye motive ediyor, bu açıdan daha iyi anladığımı düşünüyorum" (Ö1)

\section{Uzaktan hizmet içi eğitimin sınırlılıkları.}


Öğretmenlerin Uzaktan Hizmet İçi Eğitim Deneyimlerinin İncelenmesi

Uzaktan hizmet içi eğitimin sınırlılıkları ile ilgili öğretmen görüşleri analiz edildiğinde etkileşim eksikliği ve teknik sorunların öne çıktığı görülmüştür. Sınırlılıklarla ilgili bulgular Tablo 3'te özetlenmiştir.

Tablo 3. Uzaktan hizmet içi eğitimin sımırlılıkları

\begin{tabular}{ll}
\hline Tema/Kodlar & S1klık $(f)$ \\
\hline Etkileşim & \\
Öğrenen-öğretici etkileşiminin olmaması & 14 \\
& \\
Farklı bakış açısı ile bakmayı engellemesi & 3 \\
Zaman sınırlaması/yetersiz dönüt & 2 \\
Teknik sorunlar & 2 \\
\hline
\end{tabular}

Tablo 3'te görüldüğü gibi uzaktan hizmet içi eğitimin sınırlılıkları konusunda etkileşim boyutunda öğretmenlerin genel olarak etkileşim sinırlılı̆̆ından yakındığı ve karşıda bir anlatıcı olmaması nedeniyle takıldıkları yerleri soramadıklarından şikâyet ettiği gözlenmiştir. Öğretmenler, bu etkileşim eksikliğinin konu ile ilgili farklı bakış açılarının gelişmesini ve yeterli dönüt alınmasını engellediğini ifade etmişlerdir. Öğrenmenin gerçekleşmesini zorlaştıran bu etkileşim faktörü en önemli sınırlılık olarak belirtilmiştir. Bu konudaki öğretmen görüşlerinden bazıları aşağıdaki gibidir;

"Uzaktan eğitim, kafama takılan bazı şeyleri çözemiyor. Danışabileceğim ya da bana ipucu verebilecek bir birey olmadiğı için yetersiz buluyorum. Yanında seni dinleyen ya da sana eşlik eden biri olmadı̆̆g için ciddiyetle yapamıyorum bu uygulamayı"(Ö19)

"Sadece doğru cevap vermeye odaklı olduğu için konular kavranamıyor diye düşünüyorum"(Ö5)

"Birebir eğitimdeki gibi karşılaştığım sorulara anında cevap bulamıyorum. Yani bir iletişim olmuyor uzaktan eğitimde"(Ö11)

Öğretmenler uzaktan hizmet içi eğitimin teknik sorunlardan kaynaklanan bazı sınırlılıklarının olduğunu da belirtmişlerdir. Bilgisayar donanım veya yazılımlarından kaynaklanan bu sorunların zaman ve motivasyon kaybı şeklindeki etkileri ifade edilmiştir. Teknik sorunların öne çıkması teknik destek 
politikasının olmamasıyla da ilişkilendirilmektedir. Bunlardan "etkileşim sınırlılı̆̆ı" boyutuna ilişkin öğretmen yorumlarından biri aşağıda sunulmuştur;

"Eğitimi tamamladığımız halde tamamlanmadı yazıyor. Aymı eğitimi birkaç kere yaptığımız için zaman kaybı da olabiliyor bu eğitimde, ayrica soru sorabileceğimiz kimse yok, bu açılardan sınırlıydı bence"(Ö12)

\section{Uzaktan hizmet içi eğitimlerin etkililik durumu ve etkili olması için sunulan öneriler.}

Öğretmenlere bu eğitim sonunda uzaktan hizmet içi eğitimin etkili olup olmadığı sorulmuş ve cevaplar analiz edilmiştir. Uzaktan eğitimin etkili olduğunu düşünen 17, etkili olmadığını düşünen bir ve kısmen etkili olduğu yönünde görüş bildiren üç öğretmen olduğu görülmüştür. Uzaktan eğitimin kısmen etkili olduğunu ifade eden öğretmenler, bu eğitimin istenen zaman ve mekânda yapılabildiği için etkili, yüz yüze iletişim kurulmadığı için etkisiz olduğunu vurgulamışlardır. Ayrıca bu eğitimin etkili olmasının kişinin duyarlılığı ile ilgili olduğunu söylemişlerdir. Sonuçta, uzaktan eğitimin etkili bir yöntem olduğu konusunda öğretmenlerin çoğunun hemfikir olduğu ortaya çıkmıştır. Uzaktan hizmet içi eğitimin etkililik durumuna yönelik öğretmen yorumlarından bazıları aşağıdaki gibidir;

"Yüz yüze eğitime oranla daha etkilidir. Zorunluluk hissetmeden gönlümüze göre yapıyor olmak eğitimin etkili olmasında oldukça önemlidir." (Ö1)

"Çok etkili olduğunu düşünmüyorum açıķ̧ası, bu eğitimi uygularken yanımızda bir üst düzey yönetici ya da uzman olmadığı için işin ciddiyeti kalmayabiliyor ve daha rahat davranılıyor. Ben böyle görüyorum."(Ö19)

Öğretmenlere ayrıca uzaktan hizmet içi eğitimlerin niteliğinin artırılmasına ilişkin önerileri sorulmuş ve bu konudaki ifadeleri analiz edilmiştir. Önerilere yönelik analiz sonuçları Tablo 4 'te verilmiştir. 
Öğretmenlerin Uzaktan Hizmet İçi Eğitim Deneyimlerinin İncelenmesi

Tablo 4. Uzaktan hizmet içi eğitimlerin etkili olması için sunulan öneriler

\begin{tabular}{lc}
\hline Tema/Kodlar & Sıklık $(f)$ \\
\hline Eğitimin kendi branşı ile ilgili olması & 6 \\
Eğitimin belli aralıklarla verilmesi & 3 \\
Ĕ̆itim hakkında öğretmen görüşünün alınması & 3 \\
Güncel olaylara yer verilmesi & 2 \\
Eğitimin sırasında denetleme yapılması & 2 \\
Soruların yoruma dayalı ve daha kapsamlı olması & 2 \\
Programın başında eğitimin öneminin anlatılması & 1 \\
Kullanım yönergelerinin etkili hale getirilmesi & 1 \\
\hline
\end{tabular}

Tablo 4'te görüldüğü gibi öğretmenler uzaktan hizmet içi eğitimlerin etkili olmasına yönelik önerilerde eğitimlerin kapsamı, sıklığı ve sunum biçimlerine değinmişlerdir. Öğretmenlerin kapsam konusunda en çok eğitimlerin "kendi branşları ile ilgili olması" önerisinde bulundukları görülmektedir. Ayrıca öğretmenler, daha dar kapsamlı ancak sık aralıklarla tasarlanan ve sunulan eğitimlerin daha etkili olacağını düşünmektedirler. Bununla birlikte öğretmenler, bu eğitimde güncel konulara yer verilmesi gerektiği üzerinde de durmuşlardır. Kısaca kendi branşlarıyla ilgili güncel konuları da kapsayan kısa süreli ve sık aralıklarla yapılan eğitimler önerilmektedir. Bu konudaki öğretmen görüşlerinden bazıları aşağıdaki gibidir;

“Öğretmen görüşlerinden yararlanılabilir. Ayrıca öğretmenin aldığı seminerin daha çok kendi branşına uygun olması daha etkili olmasın sağlayabilir diye düşünüyorum" (Ö13)

"Benzer yöntemler uygulanmaya devam edebilir. Ancak belli aralıklarla ve seminerin içerik olarak daha az konuyla olması istek ve motivasyonu artıracaktır diyebilirim. "(Ö9)

"Uygulayıcıların bu konuya eğilmeleri, öğretmen görüşlerine yer vermeleri ve güncel olayları ön plana çıkarmaları daha etkili olacaktır bence." (Ö16) 
Tartışma ve Sonuç

Öğretmenlerin uzaktan eğitimle ilgili görüşlerine yönelik bulgularda temel olarak uzaktan eğitimin esnekliği, materyal kullanımı, etkileşim düzeyine etkisi, tercih edilebilirliği ve etkililik durumu boyutlarının öne çıktığı görülmüştür. $\mathrm{Bu}$ nedenle görüşlere ilişkin bulgular bu bağlamda ele alınıp tartışılmıştır.

Uzaktan eğitimin güçlü yönü, tercih edilebilirliği ve motivasyonu artıran etmenler boyutunda uzaktan eğitimin zaman ve mekân esnekliğinin vurgulandığ 1 ortaya çıkmıştır. Aslında uzaktan eğitimin yer ve zaman konusunda sağladığı esneklik, bu eğitimin tercih edilme sebeplerinden biri olduğu bilinmektedir (Hammond vd., 2007; Laraia vd., 2008; Elmas vd., 2007; Kesim, 2004). Bu çalışmada esneklik boyutunun bu denli öne çıkması katılımcıların iş yoğunluğu, bireysel sorumlulukları ile ilişkilendirilebilir.

Öte yandan DiBiase (2000) yaptığ çalışmada, uzaktan eğitimin zaman ve mekân konusunda sağladığı esnekliğin; öğretmen ve öğrenciyi ayırdığı, gerçeklikten uzaklaştırdığı üzerinde durmuştur. Bu sonuç, bu çalışmanın coğrafya ile ilgili olmasından kaynaklanabilir. Çünkü coğrafyayı öğrenmenin, sadece gerçek dünya ile bağlantı kurarak gerçekleşebileceği düşünülmektedir. $\mathrm{Bu}$ nedenle bazı konularda simülasyonlardan faydalanmak, uzaktan eğitimin daha gerçekçi hale gelmesini böylece daha çok alana yayılmasını sağlayabilir.

Elde edilen bulgulardan biri de uzaktan eğitimin görseller, videolar ve animasyonlarla zenginleştirilmiş olması ve bu yönüyle bir üstünlüğünün bulunmasıdır. Ayrıca eğitimin materyallerle desteklenmesinin öğretmenleri olumlu yönde etkilediği ortaya çıkmıştır. Uzaktan eğitimin çoklu materyal kullanılarak verilmesi, motivasyonu ve kalıcılığı artırmaktadır (Vasu ve Öztürk, 2009; Hixon ve So, 2009; Shepherd ve Martz, 2006; Hartnett, St George ve Dron, 2011). Bu durum, kullanılan materyallerin pek çok duyuya hitap etmesi ve öğretmenlerin dikkatini çekmesi ile ilişkilendirilebilir.

Uzaktan eğitimdeki materyal vurgusu, aslında bu eğitimlerin daha titiz biçimde hazırlanması ve yoğun materyal tasarım süreçleri içermesinin doğal bir sonucu olarak görülebilir. Yani aynı materyallerin yüz yüze eğitimlerde kullanılması halinde benzer sonuçlar bulunabilir. Nitekim Horzum ve Balta (2008) tarafından yapılan çalışmada, öğrenciler arasında materyal kullanımı açısından yüz yüze eğitimle uzaktan eğitim arasında anlamlı bir farklılık bulunamamıştır. 
Asenkron tabanlı yürütülen uzaktan eğitim uygulamasında materyal-öğrenci etkileşimleri olumlu bulunurken, öğrenen-öğrenen ve öğrenen-öğretici etkileşimleri yönünden sınırlı olduğu ortaya çıkmıştır. Başka bir ifadeyle bu çalışmada öğretmenler, uzaktan eğitim sırasında soru soramama, etkileşimde bulunamama, işbirliği halinde çalışamama konularına dikkat çekmişlerdir. Bu durum etkileşim eksikliğinin öğrencinin sosyal bulunuşluk seviyesinin düşük olmasına neden olmasıyla ilişkilendirilebilir (Rovai, 2002). Bu sınırlılık, uzaktan eğitimdeki senkron sınıflar ve video konferans dersleri sayesinde giderilebilir (Offir, Lev ve Bezalel, 2007; Hixon \& So, 2009). Web formatında telekonferans dersleri de buna örnektir (Stafford, 2005).

Uzaktan eğitimin sınırlılıklarına yönelik bulgulardan bir diğeri ise bilgisayar ve iletişimindeki teknik sorunlardır. Aslında öğrenenlerin teknik sorunlar nedeniyle uzaktan eğitimde sorun yaşadıkları bilinmektedir (Karal, Cebi ve Turgut, 2011; Fichten vd., 2009; Baran ve Çağlltay; 2010). Uzaktan hizmet içi eğitim alan kişilerin hem derse hem de uzaktan eğitime yönelik olumsuz bir tutum oluşturma potansiyeli teknik konuların önemini artırmaktadır. Bu nedenle teknik destek ve yönlendirmeler etkili bir şekilde tasarlanmalıdır. Ayrıca uzaktan eğitim programlarının daha basit ve kullanışlı hale getirilmesi konusunda çalışmalar yapılabilir.

Uzaktan hizmet içi eğitim alan öğretmenlerin bu eğitimden memnun kaldıkları ve onu tercih edilebilir buldukları görülmüştür. Uzaktan eğitim sınırlılıklarına rağmen genellikle tatmin edici bulunmuştur (Carswell ve Venkatesh, 2002; King, 2001; Tao, 2008; Fish ve Gill; 2009). Hatta uzaktan eğitimde örgün eğitime eşit veya daha kaliteli bir eğitim verildiği konusunda sonuçlar bulunmuştur (Hoesing, 2004). Ancak bu çalışmada memnuniyetin çoğunlukla esneklikle ilişkilendirildiği görülmüştür.

Uzaktan eğitimde memnuniyet sadece eğitimin şekli ile değil konu, öğrenen, ortam gibi birçok değişken tarafından etkilenmektedir. Aynı şekilde verilen uzaktan eğitimler farklı alanlarda farklı memnuniyet veya etkinlik düzeyine neden olabilir. Örneğin; Yaman (2009) çalışmasında, uzaktan eğitim ile verilen eğitimin tercih edilme düzeyinin düşük olduğunu ortaya koymuştur. Bunun nedeni, uzaktan eğitimin öğrencilerin pratik yapmasını gerektiren beden eğitimi dersinde uygulanması -motor becerilere dayalı bir konunun anlatılması- olarak görülebilir.

Çalışmalarda genel olarak uzaktan eğitimin etkili olduğu ve öğretmenlerin bilgi ihtiyaçlarını karşıladığı ortaya çıkmıştır (Shaqour, 2005; Gültekin, 2006; Usal ve Albayrak, 2005; Fahad, 2009; Elmas vd., 2007). Öte yandan uzaktan eğitimin 
etkililiği ile ilgili olumsuz sonuçlar da bulunmaktadır (Rowland ve Rubbert, 2001). Bu olumsuzluklar teknik sorunlar, destek verecek öğretim elemanı azlığı, kişilerin teknolojiye karşı tutumları ile ilişkilendirilmektedir (Muhirwa, 2009). Ancak sınırlılıkların öne çıktığı çalışmalarda bile uzaktan eğitimin bir destek eğitimi uygulaması olarak kullanılması gerekliliği vurgulanmaktadır.

$\mathrm{Bu}$ çalışmada uzaktan hizmet içi eğitimlerin genel olarak etkili bulunduğu görülmüştür. Eğitimlerin etkisi, öğrenenler tarafından esnek çalışma ortamı, çoklu ortam desteği ve materyal etkileşimlerine yer verilmesine dayandırılmıştır. $\mathrm{Bu}$ sonucu çoklu ortamın gücü ve yetişkin eğitimi prensipleriyle ilişkilendirmek mümkündür. Nitekim yetişkinlerin kendi öğrenmelerini planlayabildikleri için uzaktan eğitimi daha etkili buldukları bilinmektedir (Challis, 1999).

Yapılan araştırma, Erzurum'da bir ilköğretim okulunda bulunan yüz yüze hizmet içi eğitim almış olan öğretmenlerin bir kısmı ile sınırlıdır. Bu sınırlılığa rağmen; yapılan çalışmanın sonucunda öğretmenlerin, hizmet içi eğitimlerin uzaktan eğitim yoluyla uygulanmasını, pek çok yönden daha uygun buldukları ortaya çıkmıştır. Öğretmenler, uzaktan eğitimden yüz yüze eğitime oranla daha yüksek verim aldıklarını ifade etmektedirler. Bu sonuçlar doğrultusunda, hizmet içi eğitimlerin uzaktan eğitim yoluyla sunulmasının, öğretmenler açısından uygun olduğu söylenebilir.

\section{Öneriler}

$\mathrm{Bu}$ çalışma sonuçlarına göre, uzaktan eğitim uygulamalarının yaygınlaştırılmasına yönelik bazı önerilerde bulunmak mümkündür. Öncelikle hizmet içi eğitimlerde uzaktan eğitimin oranı artırılmalıdır. Ayrıca bu eğitimler için gerekli olan teknik desteğin sağlanması ve uzaktan hizmet içi eğitimlerin daha basit ve anlaşılır hale getirilmesi önerilebilir.

Uzaktan hizmet içi eğitimin planlanması ile ilgili olarak bir takım öneriler de sunmak mümkündür. Bunlardan biri uzaktan hizmet içi eğitim tasarlanırken hedef grupta yer alan öğretmenlerin görüşlerine yer verilmesidir. Bu görüşler sayesinde daha etkili bir eğitim oluşturulabilir ve öğretmenlerin branşlarına göre farklı eğitim tasarımlarına yer verilebilir. Önerilecek bir diğer husus ise uzaktan hizmet içi eğitimlerde öğretmenlerin dikkatini çeken ve güncel konulara yer verilmesi gerektiğidir.

Son olarak uzaktan hizmet içi eğitimin yöntemine ilişkin bazı öneriler sunulabilir. Uzaktan eğitimin etkileşimi sınırladığına yönelik öğretmen 
Öğretmenlerin Uzaktan Hizmet İçi Eğitim Deneyimlerinin İncelenmesi

görüşleri dikkate alındığında bu eğitimler sırasında veya sonrasında anlatılan konu ile ilgili soruların sorulduğu ve uzmanlar tarafından cevaplandırıldığı bir tartışma platformu oluşturulması düşünülebilir. Bu sayede öğretmenlerin birbirleriyle etkileşim halinde olmaları ve sormak istedikleri soruları paylaşabilecekleri bir ortamda bulunmaları sağlanabilir. 
Kaynakça

Baran, B. ve Çağıltay, K. (2010). Motivators and barriers in the development of online communities of practice. Eğitim Araştırmalart-Eurasian Journal Of Educational Research, 10(39), 79-96.

Carswell, A.D. ve Venkatesh, V. (2002). Learner outcomes in an asynchronous distance education envirenment. International Journal of Human-Computer Studies, 56(5), 475-494.

Cavas, B., Cavas, P., Karaoğlan, B. ve Kışla, T. (2009). A study on science teachers' attitudes toward information and communication technologies in education. The Turkish Online Journal of Educational Technology, 8 (2).

Challis, M. (1999). Amee medical education guide no. 11 (revised): PortfolioBased learning and assessment in medical education. Medical Teacher, 21(4).

Driscoll, M. (2002). Web based training creating e-learning experiences. San Fransisco: Jossey-Bass/Pfeiffer.

DiBiase, D. (2000). Is distance education a faustain bargain?. Journal of Geography in Higher Education, 24(1), 130-135.

Elmas, Ç., Bay, Ö.F., Yiğit, T., Yılmaz, E.N. ve Karataş, S. (2007). Gazi Üniversitesi Ĕ̆itim Programı. IX. Akademik Bilişim Konferansı Bildirileri, Kütahya, Türkiye.

Fahad, N. (2009). Students' attitudes and perceptions towards the effectiveness of mobile learning in King Saud University, Saudi Arabia. The Turkish Online Journal of Educational Technology, 8(2), 111-119.

Fichten, C.S., Ferraro, V. Asuncion, J.V. Chwojka, C. Barile, M. Nguyen, M.N., Klomp, R. ve Wolforth, J. (2009). Disabilities and e-Learning problems and solutions: An exploratory study. Educational Technology \& Society, 12(4), 241-256.

Fish, W.W. ve Gill, P.B. (2009). Perceptions of online instruction. The Turkish Online Journal of Educational Technology, 8(1), 53-64.

Gillies, D. (2008). Student Perspectives on videoconferencing in teacher education at a distance, Distance Education, 29(1), 107-118.

Gültekin, M. (2006). Using of distance education approach in teacher training: Anadolu University open education model. The Turkish Online Journal of Educational Technology, 5(1).

Hall, D. ve Knox, J. (2009). Issues in the education of TESOL teachers by distance education. Distance Education, 30(1), 63-85.

Hammond, F. Rennie, C. ve Dickson, J. (2007). Distance education for inuit smoking counsellors in Canada: A case report. International Journal of Circumpolar Health, 66(4), 284-286. 
Hartnett, M., St George, A. ve Dron, J. (2011). Examining motivation in online distance learning environments: Complex, multifaceted, and situationdependent. International Review of Research in Open and Distance Learning, 12(6), 20-38.

Hixon, E. ve So, H. J. (2009). Technology's role in field experiences for preservice teacher training. Educational Technology \& Society, 12(4), 294304.

Hoesing, D. J. (2004). Student perceptıons of e-learnıng in South Dakota high schools. ProQuest Dissertations and Theses, South Dakota, America.

Horton, W. (2000). Designing web based training. USA: John Wiley \& Sons, Inc.

Horzum, M.B. ve Balta, Ö. (2008). Farklı web tabanlı öğretim ortamlarında öğrencilerin başarı, motivasyon ve bilgisayar kaygı düzeyleri. Hacettepe Üniversitesi Ĕ̆itim Fakültesi Dergisi, 34, 140-154.

King, F. B. (2001). Perceptions of technology: A factor in distance education couse achievement?. Journal of Educational Computing Research. 24(4), 407418.

Karal, H., Cebi, A. ve Turgut, Y. E. (2011). Perceptions of students who take synchronous courses through video conferencing about distance education. Turkish Online Journal of Educational Technology, 10(4), 276-293.

Kesim, E. (2004). Anadolu Üniversitesi Ĕgitim Bilimleri Enstitüsünde yürütülen EYTEPE yüksek lisans programının e-öğrenme açısından değgerlendirilmesi ve ekonomik analizi. Yüksek Lisans Tezi, Anadolu Üniversitesi Eğitim Bilimleri Enstitüsü, Eskişehir Türkiye.

Laraia, B.A, Dodds, J.M, Benjamin, S., Jones, S.J. ve Carbone, E.T. (2008). Can distance education prepare future public health nutritionists? A case study. Journal of Nutrition Education and Behavior, 40(1), 34-38.

Moore, M. G. (1993). Theory of transactional distance in Keegan. Theoretical Principles of Distance Education, Routledge, New York.

Muhirwa, J.M. (2009). Teaching and Learning Against all Odds: A Video-Based Study of Learner-to-Instructor Interaction in International Distance Education. International Review of Research in Open and Distance Learning, 10(4).

Offir, B., Lev, Y. ve Bezalel, R. (2007). Surface and deep learning processes in distance education: Synchronous versus asynchronous systems. Computers \& Education, 51(2008), 1172-1183.

Özkan, R. (2005). Birey ve toplum gelişiminde öğretmenlik mesleğinin önemi. Milli Ĕ̆itim Dergisi, 33 (166).

Perreaton, H., Creed, C. ve Robinson, B. (2001). Teacher education through distance learning: Technology-curriculum-cost-evaluation. Paris: UNESCO. Higher Education Division, Teacher Education Section. 
Rovai, A. P. (2002). Sense of community, perceived cognitive learning, and persistence in asynchronous learning networks. The Internet and Higher Education, 5(4), 319-332.

Rowland, F. ve Rubbert, I. (2001). An evaluation of the information needs and practices of part-time and distance-learning students in the context of educational and social change through lifelong learning. Journal of Documentation, 57(6), 741-762.

Shaqour, A.Z. (2005). A model for integrating new technologies into preserviceteacher training programs Ajman University (A Case Study). The Turkish Online Journal of Educational Technology, 4(3).

Shepherd, M.M. ve Martz, W.B. (2006). Media Richness Theory and the distance education environment. Journal of Computer Information Systems, 47(1), 114-122.

Sonyel, B. (2004). The relationship between teacher education, professionalism and lifelong learning. Fifth International Conference on Information Technology Based Higher Education and Training.

Stafford, T.F. (2005). Understanding motivations for internet use in distance education. IEEE Transactions on Education, 48(2), 201-306.

Tao, Y. H. (2008). Typology of College Student Perception on Institutional ELearning Issues -an Extension Study of a Teacher's Typology in Taiwan. Computers \& Education, 50(4),1495-1508.

Usal, M.R. ve Albayrak, M. (2005). E-öğrenmede Bilgisayar / Ağ Altyapısı Bakımından Etkili Parametreler ve Türkiye 'nin E-öğrenmeye Hazır Bulunuşluğu. The Turkish Online Journal of Educational Technology, 2(4).

Vasu, M.L. ve Öztürk, A.O. (2009). Teaching methodology to distance education students using rich-media and computer simulation. Social Science Computer Review, 27(2), 271-283.

Yaman, M. (2009). Perceptions of students on the application of distance education in physical education lessons. The Turkish Online Journal of Educational Technology, 8(1).

Yıldırım, A. ve Şimşek, H. (2008). Sosyal bilimlerde nitel araştırma yöntemleri. Ankara: Seçkin Yayıncılık.

Yuena, A.H.K. ve Mab, W.W.K. (2008). Exploring teacher acceptance of elearning technology. Asia-Pacific Journal of Teacher Education, 36(3), 229243. 